https://www.journal-imab-bg.org

Review article

\title{
NUTRITIONAL COMPOSITION, BIOACTIVE COMPOUNDS AND HEALTH-BENEFICIAL PROPERTIES OF BLACK SEA SHELLFISH
}

\author{
Veselina Panayotova ${ }^{1}$, Albena Merdzhanova ${ }^{1}$, Diana A. Dobreva ${ }^{1}$, Kameliya \\ Bratoeva $^{2}$, Lubomir Makedonski ${ }^{1}$ \\ 1) Department of Chemistry, Faculty of Pharmacy, Medical University of Varna, \\ Bulgaria. \\ 2) Department of Physiology and Pathophysiology, Faculty of Medicine, Medical \\ University of Varna, Bulgaria.
}

\begin{abstract}
Marine bivalves are characterized as high nutritional, easily digestible food, low calories but high in proteins. The activity of biologically active substances in shellfish from the Black Sea region is very poorly studied. A small number of publications devoted to the functional activity of tissue and/or extracts from Black Sea shellfish are found in the literature. The main scientific objective of the project is to study the quality and functional potential of three species of Black Sea bivalves: black mussel (Mytilus galloprovincialis), striped venus clam (Chamelea gallina) and wedge clam (Donax trunculus). Seafood nutrition data is needed to assess their contribution to nutrient intake of individuals and populations but also to the development of nutrition guidelines as well as for labelling purposes. Specific information on the nutrient content of regional foods, including seafood, is the basis of a number of food strategies and policies, and increasingly in the fields of agriculture, fisheries and aquaculture. In many cases, this data may help specialized public authorities and public organizations with regard to food quality and related costs, as well as developing adequate strategies and policies aiming to improve the nutritional literacy of the population and solve issues of malnutrition and prevention of socially significant diseases (chronic non-communicable diseases, CND) with the help of wholesome foods, such as bivalves.
\end{abstract}

Keywords: Black Sea shellfish, functional potential, nutrition

\section{BACKGROUND}

Marine shellfish are characterized as easily digestible food, low in calories, but nutrient-dense. According to the Food and Agriculture Organization (FAO), the absorption coefficients of proteins and lipids contained in the edible tissue of shellfish are above 0.9 , which indicates their high nutritional value. Although the lipid content is low, so far, this group of primary metabolites has shown the highest potential to develop commercially significant functional foods and nutritional supplements. The predominant polar lipids rich in polyunsaturated fatty acids (PUFA) increase the quality of shellfish as nutraceuticals. Contemporary studies show the potential of bivalves as a very good source of antioxidants (phenolic compounds) exhibiting antimicrobial activity.

Specific information on the nutrient content of regional foods, especially seafood, is on the basis of a number of government food strategies and policies. Data may help specialized public authorities and organizations with regard to food quality and related costs; developing adequate strategies and policies aiming to improve the nutritional literacy of the population; and solve issues of malnutrition and prevention of socially significant diseases (chronic noncommunicable diseases, NCD) with the help of wholesome foods, such as shellfish. According to the World Health Organization (WHO), unhealthy eating patterns are among the major risk factors for cardiovascular disease (CVD). CVDs are among the main causes of morbidity and mortality of the population in developed countries. The spread of the NCD is epidemic (CVD in particular), which increases their negative impact on the socio-economic development of societies [1]. In 2010 CVDs account for $67.5 \%$ of the deaths in Bulgaria. In 2013, the Council of Ministers of the Republic of Bulgaria adopted a National Program for Prevention of Chronic Non-Communicable Diseases 2014-2020. There are serious nutritional challenges in our country which give rise to the need to undertake activities to support a healthy diet and ensure safe and healthy food for the entire population.

Shellfish are used mainly as food, but there are numerous products sold worldwide as high-value nutraceuticals [2]. Studies have shown that lipid extracts and freeze-dried mussel powder of mussels have numerous health benefits, including the ability to reduce inflammation [3-7].

In Bulgaria, there are three commercial shellfish species - black mussel (Mytilus galloprovincialis), striped venus clam (Chamelea gallina) and wedge clam (Donax trunculus). These Black Sea species can be valuable sources of biologically active substances for Bulgarian consumers due to the fact that they are sustainable species applicable to aquaculture. The aim of this study is to determine the quality and functional potential of three species of Black Sea 
bivalves: black mussel (Mytilus galloprovincialis), white sand clams (Chamelea gallina and Donax trunculus).

\section{BLACK SEA SHELLFISH}

\section{Mytilus galloprovincialis}

The Mediterranean mussel Mytilus galloprovincialis is a species of great economic importance in the Black Sea region. According to the Executive Agency for Fisheries and Aquaculture (EAFA), Mytilus galloprovincialis is the only representative of the Phylum Mollusca, subjected to the aquaculture sector in Bulgaria. The number of existing Black Sea mussel farms is 45 with a total production of 2520 tons in 2014 [8]. During the last two years the chemical composition (proteins, lipids and carbohydrates), the fatty acid profile, the content of fat-soluble vitamins (A, E and $\mathrm{D}_{3}$ ), cholesterol and carotenoids of cultivated black mussel from the Bulgarian coast were studied. The seasonal changes for the described compounds have been followed, and it has been found that this species has valuable nutritional qualities and is recommended to be included in various diets. It is estimated that $100 \mathrm{~g}$ of Mytilus galloprovincialis delivers more than $150 \%$ of the recommended daily intake (RDI) of long-chain omega-3 PUFA (0.97g per $100 \mathrm{~g}$ of edible portion), more than $55 \%$ of vitamin $\mathrm{D}_{3} \mathrm{RDI}$ and high amounts of $\beta$-carotene and astaxanthin [9-12].

\section{Chamelea gallina}

Striped venus clam (Chamelea gallina) is widespread in the Mediterranean basin and also abundant throughout the Aegean, Black and Azov Seas [13]. There are only a few studies on the chemical composition of this species harvested in the Adriatic [14] and the Marmara Sea [15].

\section{Donax trunculus}

Recently more and more attention has been paid to wedge clam (Donax trunculus) along the Bulgarian Black Sea coast. The species is characterized as a very good source of protein and PUFA [16, 17]. Yet, literature data lack of information on the chemical composition of Chamelea gallina and Donax trunculus from the Black Sea which raises the need for systematic studies on their quality as food alternatives of black mussel and species rich in functionally active compounds with high potential for cultivation in the Black Sea waters.

\section{PRELIMINARY RESULTS}

\section{Proximate composition}

Table 1 presents the proximate composition (proteins, carbohydrates and lipids) of the studied species. Proteins were the major macronutrients in investigated Black Sea shellfish. The black mussel showed two folds higher protein content, compared to the white clams. Chamelea gallina showed the lowest carbohydrate and highest lipid content. Based on the reported protein levels, all species can be classified as "high in protein" [18]. Some authors have suggested that protein content is correlated with mussels' reproductive cycles and environmental conditions [19]. $M$. galloprovincialis from Bulgarian coast showed the different protein levels [10] compared to the same species inhabiting the Romanian and Turkish parts of the Black Sea [20, 21]. Both lipids and carbohydrates are energy supplying macronutrients, therefore their contents are related mainly to shellfish reproductive cycle. Their composition varies significantly throughout the year and in different habitats. This explains the differences in carbohydrate contents reported for mussels from different parts of the Black Sea [20, 21]. On the other hand, scientific literature lacks information on the other two species - Chamelea gallina and Donax trunculus, in terms of their chemical composition [14, 17]. Lipids are minor constituents of shellfish meat. Their amount and composition are strongly species specific, but also influenced by different factors acting simultaneously and provoking temporary changes in lipid content. Despite that, presented results characterize edible Black Sea shellfish as species with low lipid content.

Table 1. Proximate composition of Mytilus galloprovincialis, Chamelea gallina and Donax trunculus

\begin{tabular}{|l|c|c|c|c|}
\hline Shellfish species & Proteins & Carbohydrates & Lipids & Reference \\
\hline Mytilus galloprovincialis & $17.4-19.9 \mathrm{~g} / 100 \mathrm{~g} \mathrm{ww}$ & $2.0-2.7 \mathrm{~g} / 100 \mathrm{~g} \mathrm{ww}$ & $1.4-2.9 \mathrm{~g} / 100 \mathrm{~g} \mathrm{ww}$ & {$[10]$} \\
\hline Chamelea gallina & $8.51-9.7 \mathrm{~g} / 100 \mathrm{~g} \mathrm{ww}$ & $0.7-1.6 \mathrm{~g} / 100 \mathrm{~g} \mathrm{ww}$ & $2.2-5.0 \mathrm{~g} / 100 \mathrm{~g} \mathrm{ww}$ & {$[14]$} \\
\hline Donax trunculus & $8.13-10.61 \%$ of ww & $2.31-3.18 \%$ of ww & $0.69-1.33 \%$ of ww & {$[15]$} \\
\hline
\end{tabular}

\section{Fatty acid composition}

Until now, lipids are the primary metabolites from shellfish that have shown the highest potential for commercial functional foods and additives. Although oily fish is considered the main source of long-chain omega-3 PUFA, shellfish could be a sustainable, alternative source of these fatty acids. Moreover, lipid classes present in shellfish oil comprise neutral, polar lipids, sterols and sterol esters, vitamins and carotenoids. In contrast to other species, the amount of available information on lipid composition from the studied species is comparably small. However, lipid extracts of Mytilus species exhibited anti-inflammatory [5], anti-tumour effects [6] and wound healing properties [7].

Fatty acid composition of the studied species is presented in Table 2. In mussels' tissues, fatty acids (FA) are derived mainly from diets or through biosynthesis. The FAs, especially essential fatty acids (EFA) are intricately related to crucial physiological and biochemical processes in living organisms. 
Table 2. Fatty acid composition (\% of total FA) of Mytilus galloprovincialis, Chamelea gallina [14] and Donax trunculus [17]

\begin{tabular}{|l|c|c|c|}
\hline & Mytilus galloprovincialis & Chamelea gallina & Donax trunculus \\
\hline SFA & $19.8-41.7$ & $29.1-39.3$ & $12.6-19.2$ \\
\hline MUFA & $5.5-18.9$ & $14.2-23.4$ & $31.6-46.2$ \\
\hline PUFA & $47.1-71.9$ & $41.6-48.1$ & $19.5-34.9$ \\
\hline n-3 & $36.5-64.8$ & $33.7-41.9$ & $5.6-9.7$ \\
\hline n-6 & $1.8-11.5$ & $3.61-9.07$ & $0.27-0.29$ \\
\hline n-6/n-3 & $0.06-0.51$ & $0.10-0.22$ & $1.22-1.33$ \\
\hline PUFA/SFA & $1.1-3.5$ & $1.22-1.43$ & \\
\hline
\end{tabular}

SFA - saturated fatty acids; MUFA - monounsaturated fatty acids; PUFA - polyunsaturated fatty acids; $n$-3 omega-3; n-6 - omega-6

It is known that aquatic organisms such as mollusks are primary sources of $\AA$ FAs, therefore determining the FA profile of bivalves could help us to better understand the beneficial potential of their lipids. In addition, the growing interest in new sources of essential fatty acids necessitates the exploration of poorly studied marine species such as the white clams $C$. gallina and D. trunculus. In this study, the FA profile of the three species presented a similar distribution: PUFA $>$ SFA $>$ MUFA. The high quality of bivalve lipids is well demonstrated by the prevalence of PUFAs group in total lipids fractions in all species. Moreover, the physiologically active n-3 FAs accounted between $63 \%$ and $85 \%$ of total PUFA and up to $65 \%$ of total FA in studied species. The well-known functional activities of these FAs are related with their platelet anti-aggregation and anti-thrombotic effects, hypocholesterolemic and blood pressure-reducing properties $[5,14,15]$. In addition, the low levels of n-6 PUFAs significantly increase the benefits of mollusks lipids, due to low $n-6 / n-3$ ratio, which could influence positively cardiovascular diseases (CVD). The WHO recommends the replacement of high SFA intake with PUFA or MUFAs, preferably from seafood origin in order to decrease the $n-6 / n-3$ ratios [1]. Besides $n-6 / n-3$, another important key ratio is PUFA/SFA, which is used for nutrition quality assessment, proposed as a measure of the tendency of the diet to affect the incidence of CVD. The presented results for both important key indicators (Table 2) well illustrated the beneficial nutritional quality of studied species. According to the Department of Health [22] recommended a PUFA/SFA ratio within the range: $0.5-4.0$. Low n-6/n-3 and high PUFA/SFA ratios in bivalve mollusks could synergistically increase the options of establishing a healthy and well-balanced proportion between both biochemically active long chain PUFA classes in the human diet, fundamental in the prevention of non-communicable chronic diseases, including CVD.

The results for FA profile for two white clams $C$. gallina and D. trunculus from the Adriatic Sea and Marmara Sea (Table 2) confirmed the promising potential of these species $[14,17]$. The differences of FA composition found between the Black Sea mussel, and the two other species can be explained by the fact that FAs composition of marine mollusks depends on the environmental factors, such as temperature, salinity, pollution and diet. Moreover, the lack of information for FA composition of the same bivalves from the Black Sea imposes the need for detailed study of these species. Therefore, providing new and up-to-date information on the FA composition of $C$. gallina and D. trunculus as alternative sources of EFA is very important for dietitians, pharmacists and consumers.

\section{Unsaponifiable lipids composition}

The composition of the unsaponifiable lipid fraction extracted from the total lipids of M. galloprovincialis and C. gallina is presented in Table 3 .

Table 3. Unsaponifiable lipid components in Mytilus galloprovincialis [unpublished data] and Chamelea gallina [14]

\begin{tabular}{|l|c|c|}
\hline & Mytilus galloprovincialis & Chamelea gallina \\
\hline Wet weight $(\mu \mathrm{g} / 100 \mathrm{~g})$ & & \\
\hline Vitamin A & $21.1-64.0$ & $\operatorname{tr}$ \\
\hline Vitamin $\mathrm{D}_{3}$ & $5.5-24.0$ & - \\
\hline Astaxanthin & $23.9-57.3$ & $1.64-31.1$ \\
\hline$\beta$-Carotene & $318-950$ & - \\
\hline
\end{tabular}




\begin{tabular}{|l|c|c|}
\hline Wet weight $(\mathrm{mg} / 100 \mathrm{~g})$ & & \\
\hline Cholesterol & $24.6-46.4$ & $28.3-34.2$ \\
\hline Brassicasterol & $10.2-35$ & $1.2-8.3$ \\
\hline Stigmasterol + Campesterol & $3.7-7.9$ & $2.7-5.2$ \\
\hline$\beta-$ Sitosterol & $0.5-5.2$ & $1.1-2.4$ \\
\hline Vitamin E & $1.4-7.7$ & $0.48-1.16$ \\
\hline
\end{tabular}

Fat-soluble vitamins, carotenoids and sterols are essential metabolites for the normal growth, metabolism and reproductive cycle of bivalves. Carotenoids are very important nutrients since they act as a precursor of vitamin A and participate in cell protection. These compounds can prevent lipids from peroxidation, which characterizes a number of degenerative diseases. Other important bioactive compounds are phytosterols. Consumption of phytosterols inhibits intestinal absorption of cholesterol and thus reduce the blood cholesterol levels in the human organism. Moreover, marine bivalves could be an alternative source of antioxidant compounds (such as vitamin E, $\beta$-carotene, astaxanthin) and sterols, including phytosterols. The carotenoid and sterol profile of bivalves reflects their diet composition, which comprises mainly of zoo- and phytoplankton, microalgae with their speciesspecific carotenoids and phytosterols. It is known that bivalve molluscs have limited capacity for cholesterol synthesis or bioconversion of phytosterols into cholesterol [14]. Sterols are important components of cell membranes and usually cholesterol is prevalent in their fraction. The results presented for both molluscs' sterol composition confirmed that cholesterol is the major component (24.6$46.4 \mathrm{mg} / 100 \mathrm{~g} \mathrm{ww})$. The observed differences in the other phytosterols, especially for brassicasterol contents can be explained with differences in phytoplankton species, specific for the Black Sea and the Adriatic Sea. The reported higher sterol content in black mussel supposed it good potential as sources of these bioactive compounds. In addition, vitamin $\mathrm{D}_{3}$ content in black mussel is in the range from 5.5 to $24 \mu \mathrm{g}$ per $100 \mathrm{~g} \mathrm{ww}$, which supplies between 37 and $160 \%$ of the recommended daily intake [23].

The lack of information for fat soluble vitamins, carotenoids and sterols contents in both white bivalves, imposes the need for quantitative determination of these biologically active compounds. In this way, the potential of mussels as perspective sources from a pharmaceutical and nutritional point of view can be much more thoroughly and comprehensively evaluated.

\section{CONCLUSION AND FUTURE PERSPECTIVES}

In past years, marine invertebrates are attracting significant interest not only in terms of primary metabolites - proteins, lipids and carbohydrates. The bioactive potential of smaller molecules or secondary metabolites in marine bivalves makes them even more valuable sources for the production of functional foods and nutraceuticals. $\mathrm{Nu}$ merous scientific studies have established a direct causal relationship between seafood consumption (shellfish) and the reduction of the risk of socially significant CVD. This is associated with the requirement for increased intake of n-3 PUFA, essential elements, fat-soluble vitamins, sterols and antioxidants such as carotenoids. Presented preliminary results for the chemical and bioactive composition of three bivalve species described them as valuable and promising sources. High protein content, essential fatty acids and other bioactive compounds confirm their promising potential for the development of health-beneficial products.

There is limited or lacking information related to the quality proximate and lipid composition of white clams from the Bulgarian Black Sea coast. Therefore, the implementation of the study will result in a large amount of data related to the content of these valuable bioactive substances in Black Sea shellfish. The expected results of future research will provide a new data on the chemical and lipid composition, new data on the biological activity (antibacterial, antimycotic and antioxidant potential) of Mytilus galloprovincialis, Chamelea gallina and Donax trunculus. These data can be used in different fields - preparation of prophylactic and specialized nutritional regimes, nutraceuticals and pharmaceuticals. High-quality research focuses on gaining new knowledge about the nutrient content and quality of less studied, but locally available seafood. The three Black Sea shellfish species can be valuable and sustainable natural sources of bioactive compounds for Bulgarian consumers due to the fact that they could be easily subjected to aquaculture along our coast.

\section{ACKNOWLEDGMENTS}

The authors would like to thank the National Science Fund of Bulgaria for the financial support. The study is a part of a project "Biological activity and functional properties of Black Sea shellfish tissues (Mytilus galloprovincialis, Chamelea gallina and Donax trunculus) as sources of natural nutraceuticals" No. KP-06-OPR03/11 from 18. Dec. 2018 


\section{REFERENCES:}

1. WHO, Better food and nutrition in Europe: a progress report monitoring policy implementation in the $\mathrm{WHO} \mathrm{Eu}-$ ropean Region. 2018, 58 pp

2. Grienke U, Silke J, Tasdemir D. Bioactive compounds from marine mussels and their effects on human health. Food Chem. 2014 Jan 1;142:4860. [PubMed] [Crossref]

3. Miller MR, Pearce L, Bettjeman BI. Detailed distribution of lipids in Greenshell ${ }^{\mathrm{TM}}$ mussel (Perna canaliculus). Nutrients. 2014 Apr 11;6(4):145474. [PubMed] [Crossref]

4. Ahmad TB, Liu L, Kotiw İ, Benkendorff K. Review of anti-inflammatory, immune-modulatory and wound healing properties of molluscs. J Ethnopharmac. 2018 Jan 10;210:156178. [PubMed] [Crossref]

5. McPhee S, Hodges LD, Wright PF, Wynne PM, Kalafatis N, Macrides TA. Prophylactic and therapeutic effects of Mytilus edulis fatty acids on adjuvant-induced arthritis in male Wistar rats. Prostaglandins Leukot Essent Fatty Acids. 2010;82(2-3):97103. [PubMed] [Crossref]

6. Kim EK, Kim YS, Lee SJ, Jeon YJ, Ahn CB, Kim YT, et al. Effect of partially purified lipid from the mussel Mytilus coruscus on apoptosis in cancer cells. J Korean Soc Appl Biol Chem. 2011;54(1):59-65. [Crossref]

7. Badiu DL, Balu AM, Barbes L, Luque R, Nita R, Radu M, et al. Physicochemical characterisation of lipids from Mytilus galloprovincialis (L.) and Rapana venosa and their healing properties on skin burns. Lipids. 2008; 43(9):829-41. [PubMed] [Crossref]

8. Multiannual National Strategic Plan for Aquaculture in Bulgaria 20142020. 2014, 82 pp. [in Bulgarian] [nternet]

9. Merdzhanova A, Dobreva DA,
Makedonski L, Fat soluble vitamins and fatty acid composition of wild Black Sea mussel, rapana and shrimp. Analele Universitatii "Ovidius" Constanta Seria Chimie. 2014; 25(1):15-23.

10. Merdzhanova A, Dobreva DA, Georgieva S. Nutritional evaluation of aquaculture mussels (M. galloprovincialis) from the Black Sea, Bulgaria Analele Universitatii "Ovidius" Constanta - Seria Chimie. 2016; 27(1): 1-7.

11. Merdzhanova A, Dobreva DA, Panayotova V. Assessment of Proximate and Bioactive Lipid Composition of Black Sea Mussels (M. galloprovincialis) from Bulgaria. In: Biological Resources of Water. Edited by Ray S. Intech Open. 2017; Chapter 9. pp.181200. [Crossref]

12. Stancheva M, Merdzhanova A, Dobreva DA. Fat soluble vitamins, cholesterol and fatty acid composition of wild and farmed black mussel (Mytilus galloprovincialis) Consumed in Bulgaria. J Aquat Food Prod Technol. 2016 Feb;26(2):181-91. [Crossref]

13. Scarlato OA, Starobogatov YE. Class - Bivalvia. Keys to the Fauna of the Black and Azov Seas. Naukova Dumka. 1972; 3:178-249 [in Russian]

14. Orban E, Di Lena G, Nevigato T, Casini I, Caproni R, Generoso S, et al. Nutritional and commercial quality of the striped venus clam, Chamelea gallina, from the Adriatic Sea. Food Chem. 2007; 101(3):1063-70. [Crossref]

15. Colakoglu FA, Ormanci HB, Berik N, Kunili IE, Colakoglu S. Proximate and Elemental Composition of Chamelea gallina from the Southern Coast of the Marmara Sea (Turkey). Biol Trace Elem Res. 2011; 143:983-991. [Crossref]

16. Boussoufa D, Ghazali N, Viciano E, Navaro JC, El Cafsi M. Seasonal variation in condition and fatty acid composition of coquina clam, Donax trunculus (Linnaeus 1758) (Mollusca: Bivalvia) from the Tunisian coast. $\mathrm{Cah}$ Biol Mar. 2011; 52: 47-56

17. Ozden O, Erkan N, Ulusoy S. Seasonal Variations in the Macronutrient Mineral and Proximate Composition of Two Clams (Chamelea Gallina and Donax Trunculus). Int J Food Sci Nutr. 2009 Aug;60(5):402-12. [PubMed] [Crossref]

18. Regulation (EC) No 1924/2006 of the European Parliament and of the Council of 20 December 2006 on nutrition and health claims made on foods. OJEU. 30.12. 2006; L404/9-25. [Internet]

19. Soumady D, Asokan S. A study on protein content in selected organs of Perna viridis at Tranquebar coastal waters, Tamilnadu, India. World J Zool. 2011;6(4):360-63.

20. Sirbu R, Bechir A, NegreanuPîrjol T, Sava C, Negreanu-Pîrjol B, Zaharia T, et al. Studies on the nutrient content of species Mytilus galloprovincialis of the Black Sea. Scientific Study and Research: Chemistry and Chemical Engineering, Biotechnology, Food Industry. 2011; 12(3):221-28.

21. Dernekbasý S, Oksuz A, Celik YM, Karayucel I, Karayucel S. The fatty acid composition of cultured mussels (Mytilus galloprovincialis Lamarck 1819) in offshore longline system in the Black Sea. J Aquac Mar Biol. 2015; 2(6):00049. [Crossref]

22. Department of Health 1994. Nutritional aspects of cardiovascular disease: Health and social subjects (Report No 46) HMSO, London, $187 \mathrm{p}$.

23. [Ordinance No.1/22.01.2018 on the physiological feeding of population.] Ministry of Health, Bulgaria. [in Bulgarian] [Internet]

Please cite this article as: Panayotova V, Merdzhanova A, Dobreva DA, Bratoeva K, Makedonski L. Nutritional Composition, Bioactive Compounds and Health-Beneficial Properties of Black Sea Shellfish. J of IMAB. 2020 Jul-Sep;26(3):32933297. DOI: https://doi.org/10.5272/jimab.2020263.3293

Received: 10/09/2019; Published online: 17/08/2020

Address for correspondence:

Veselina Panayotova

Department of Chemistry, Faculty of Pharmacy, Medical University of Varna 84 “Tzar Osvoboditel” Blvd, Varna, Bulgaria

E-mail: veselina.ivanova@hotmail.com, 